\title{
Fikih Maqāṣidi dalam Fatwa Majelis Ulama Indonesia tentang Penggunaan Vaksin Covid-19 Produk Astrazeneca
}

\author{
Moch. Nurcholis \\ Institut Agama Islam Bani Fattah Jombang, Indonesia \\ moch.nurcholis@iaibafa.ac.id
}

\begin{abstract}
The rapid advancement of fiqh discourse has reached a thematic study phase and has shifted to a philosophical style. The philosophical type can be carried out through an integrated combination of fiqh and maqasid al-shari'ah to produce a fiqh maqasid discourse in the Indonesian Ulama Council's Fatwa Number 14 of 2021. Fiqh maqasid epistemology also needs to be addressed in this discourse. Efforts to reveal the existence of fiqh maqasid in the MUI fatwa and its epistemological building in this study used content analysis methods and Islamic legal philosophy as the approach. This research concludes that the fiqh maqasid paradigm has been applied in the MUI fatwa by using tarjih based on maqasid al-shari'ah. In the realm of epistemology, fiqh maqasid originates from transcendental texts supported by ijma', and qawa'id al-fiqh. The paradigm in fiqh maqasid involves an integral relationship between ushul al-fiqh, fiqh, reality, maqasid al-shari'ah, and qawa'id al-fiqh. While the truth in fiqh maqasid is based on the pragmatic theory of truth using instruments of utility, workability, satisfactory consequences.
\end{abstract}

Keywords: Astrazeneca Products, Fatwa of the Indonesian Ulema Council, Fiqh of Maqasid, Use of the Covid-19 Vaccine

\begin{abstract}
Abstrak
Pesatnya kemajuan diskursus fikih telah sampai pada fase kajian yang bersifat tematik dan mulai bergeser pada corak filosofis. Corak filosofis dapat dilakukan melalui perpaduan integral antara fikih dan maqashid al-syariah sehingga menghasilkan diskursus fikih maqāsidi sebagaimana dalam fatwa Majelis Ulama Indonesia Nomor 14 Tahun 2021. Epistemologi fikih maqāsidi juga perlu diketengahkan dalam diskursus ini. Upaya dalam mengungkap keberadaan fikih maqāsidi dalam fatwa MUI tersebut serta bangunan epistemologinya pada penelitian ini digunakan metode content analysis dan filsafat hukum Islam sebagai pendekatannya. Penelitian ini menyimpulkan bahwa paradigma fikih maqāsidi telah diterapakan dalam fatwa MUI tersebut melalui penggunaan tarjih dengan basis maqāsid al-shari $\bar{C}^{\prime} a h$. Dalam ranah epistemologi, fikih maqāsidi bersumber dari teks transendental didukung konsensus, dan beberapa kaidah fikih. Paradigma dalam fikih maqāsidi melibatkan hubungan integral antara ushul fikih, fikih, realitas, maqāsid al-shari 'ah, dan kaidah fikih. Sedangkan kebenaran dalam fikih maqāsidi didasarkan pada teori kebenaran pragmatis dengan menggunakan instrumen utility (nilai guna), workability (fungsi kerja), satisfactory consequencies (berdampak kepuasan).
\end{abstract}

Kata Kunci: Produk Astrazeneca, Fatwa Majelis Ulama Indonesia, Fikih Maqāșidi, Penggunaan Vaksin Covid-19

\section{Pendahuluan}

Fikih pada era kelahirannya merupakan praktik ideal keagamaan yang dilakukan oleh Nabi SAW. Pada zaman Nabi, fikih belum berwujud sebagai sebuah ilmu yang 
mandiri. Bahkan, klasifikasi hukum seperti wājib, ḥaram, sunnah, makrūh, mubāh merupakan satu hal yang dirumuskan dan disistematisasikan belakangan oleh para fuqahà'. Sama halnya pada era Nabi, fikih pada era sahabat belum juga berbentuk sebagai sebuah kajian keilmuan yang secara spesifik mengkaji persoalan hukum terapan untuk persoalan yang faktual. ${ }^{1}$ Hanya saja, pada era ini fikih sudah mulai tumbuh dalam wujud serangkain penemuan hukum pada persoalan yang belum pernah terjadi pada era Nabi. Terminologi fikih pada era awal Islam dimaknai sebagai agama Islam itu sendiri yang di dalamnya mencakup kajian tentang seluruh dimensi-dimensi keagamaan. Makna fikih semacam ini sebagaimana tampak dalam QS. Al-Taubah (9): 122, dan hadis Nabi riwayat al-Bukhārī. ${ }^{2}$ Pada gilirannya, kajian fikih terus mengalami perkembangan yang ditandai dengan kelahiran mazhab bercorak kedaerahan (Hijaz dan Kufah) dan dilanjutkan dengan mazhab perorangan. Seiring dengan kematangannya, kajian fikih beranjak pada tema krusial dan isu faktual.

Kajian fikih secara tematik telah banyak dilakukan, baik oleh cendekiawan muslim dari Indonesia, mapun dari luar negeri. Diantara karya fikih tematik seperti fikih sosial, ${ }^{3}$ fikih demokratik, ${ }^{4}$ fikih lintas agama, ${ }^{5}$ fikih lingkungan hidup, ${ }^{6}$ fikih minoritas, ${ }^{7}$ fikih tradisi,${ }^{8}$ fikih Indonesia, ${ }^{9}$ fikih keseharian buruh migran, ${ }^{10}$ fikih kawin anak, ${ }^{11}$ fikih

${ }^{1}$ Mun'im A. Sirry, Sejarah Fiqih Islam: Sebuah Pengantar (Surabaya: Risalah Gusti, 1995), 9.

${ }^{2}$ Muhammad Ibn Ismā’il Al-Bukhāri, Sahịh Al-Bukhārī, Vol. 1 (Beirut: Dār Ibn Kathīr, 1987), 39.

${ }^{3}$ Sahal Mahfudz, Nuansa Fiqh Sosial(Yogyakarta: LKiS, 1994); Ali Yafie, Menggagas Fiqih Sosial Dari Doal Lingkungan Hidup, Asuransi Hingga Ukhuwah (Bandung: Mizan, 1994); Abd. Rahman, Fikih Sosial: Individu dan Masyarakat dalam Interaksi, ed. oleh Darmawati (Makassar: Alauddin University Press, 2012); Muhammad Yusuf Chudlori, Fikih Sosial Praktis Dari Pesantren (Bandung: CV Marja, 2015); Umdatul Baroroh dan Tutik Nurul Jannah, Fikih Sosial: Masa Depan Fiqh Indonesia (Pati: Pusat Fisi, 2016); Nur Kholis Majid, Fikih Sosial Responsif \& Solutif(Surabaya: CV. Raziev Jaya, 2018).

${ }^{4}$ Said Aqiel Siradj, Islam Kebangsaan: Fiqih Demokratik Kaum Santri (Jakarta: Pustaka Ciganjur, 1999), 1.

${ }^{5}$ Nurcholish Madjid dkk., Fiqih Lintas Agama: Membangun Masyarakat Inklusif-Pluralis, ed. oleh Mun'im A. Sirry (Jakarta: Yayasan Wakaf Paramadina, 2004), 1.

${ }^{6}$ Ali Yafie, Merintis Fiqh Lingkungan Hidup (Jakarta: Ufuk Press, 2006), 1.

${ }^{7}$ Ahmad Imam Mawardi, Fiqh Minoritas: Fiqh al'Aqalliyat dan Evolusi Maqashid al-Syari'ah dari Konsep ke Pendekatan (Yogyakarta: LKiS, 2010), 1.

${ }^{8}$ Ahmad Bisyri Syakur, Fiqih Tradisi: Cara Baru Memandang Tradisi Islam di Indonesia(Bandung: Salamadani, 2013), 1 .

${ }_{9}$ Marzuki Wahid, Fiqh Indonesia: Kompilasi Hukum Islam dan Counter Legal Draft Kompilasi Hukum Islam dalam Bingkai Politik Hukum Indonesia (Cirebon: Penerbit Marja, 2014), 1.

${ }^{10}$ Imam Nakha'i dan Marzuki Wahid, Seri Fiqih Keseharian Buruh Migran(Bandung: CV. Mujahid Press, 2015), 1.

${ }^{11}$ Mukti Ali dkk., Fikih Kawin Anak(Depok: PT. Melvana Media Indonesia, 2015), 1. 
korupsi, ${ }^{12}$ fikih ikhtilaf, ${ }^{13}$ fikih tata Negara, ${ }^{14}$ fikih persaingan usaha, ${ }^{15}$ fikih pernikahan, ${ }^{16}$ fikih lalu lintas, ${ }^{17}$ fikih wabah. ${ }^{18}$ Di samping itu, beberapa karya Ulama' muslim kontemporer luar negeri juga cukup banyak ditemukan dalam kajian semacam ini, seperti fikih statis dan fikih dinamis, ${ }^{19}$ dan fikih pergaulan anak kepada orang tua. ${ }^{20}$ Namun demikian, diantara karya yang mendiskusikan tentang kajian fikih, belum banyak ditemukan kajian fikih yang bercorak filosofis. Sebuah kajian yang memadukan antara fikih dengan filsafat hukum Islam, khususnya maqāsid al-shari 'ah. Pada titik inilah penelitian ini menemukan posisi strategisnya untuk mengisi kekosongan kajian tersebut melalui gagasan tentang fikih maqashidi. Sebuah bangunan paradigma fikih yang berorientasi pada jaminan keterwujudan maqāsid al-sharī'ah, meliputi perlindungan ekspresi keberagamaan (hifz al-din), perlindungan dan pengoptimalan kualitas hidup (hifz al-nafs), penguatan kualitas dan garis keturunan (hifz al-nasl), kualitas nalar intelektual (hif̧ al-'aqI), dan pemenuhan dan pemerataan ekonomi (hifz al-māl). ${ }^{21}$

Diantara karya yang membahas keterkaitan antara fikih dengan maqāṣid alsharī ah adalah tulisan Jāsir 'Awdah berjudul fiqh al-maqāshid. Meski sekilas tampak ada persamaan pada sisi redaksional, namun pembahasan dalam karya tersebut berkisar pada persoalan bagaimana "memahami kerangka al-maqāshid'. Kajian Jāsir 'Awdah ini dapat diposisikan sebagai batasan umum terhadap penggunaan al-maqāshid sebagai based ijtihād. ${ }^{22}$ Dalam kajian ini, Jāsir 'Awdah tidak mengkaji secara spesifik tentang penerapan fikih maqāshidi dalam sebuah kasus aktual sebagaimana yang penulis lakukan dalam penelitian itu. Selain Jāsir 'Awdah ditemukan pula kajian tentang ijtihād maqāșidi

\footnotetext{
${ }^{12}$ Harun Al-Rasyid, Fikih Korupsi: Analisis Politik Uang di Indonesia Dalam Perspektif Maqashid al-Syari'ah (Jakarta: Kencana, 2017), 1.

${ }^{13}$ Alifatul Arifiati, Menggagas Fiqh Ikhtilaf: Potret dan Prakarsa Cirebon, ed. oleh Marzuki Wahid (Cirebon: Lembaga Fahmina, 2017), 1.

${ }^{14}$ Afifuddin Muhajir, Fiqh Tata Negara (Yogyakarta: CV. IRCiSOD, 2017), 1.

${ }^{15}$ Rumadi Ahmad, Fikih Persaingan Usaha (Jakarta: PP LAKPESDAM NU, 2019), 1.

16 Jamal Ma'mur Asmani dan Umdatul Baroroh, Fiqh Pernikahan: Studi Pernikahan Usia Dini Dalam Pandangan Ulama (Yogyakarta: Aswaja Pressindo, 2019), 1.

${ }^{17}$ M. Lathoif Ghozali dkk., Fiqih Lalu Lintas: Tuntunan Islam Dalam Berkendara Secara Aman (Surabaya: UIN Sunan Ampel Press, 2019), 1.

18 Achmat Hilmi, Jamaluddin Mohammad, dan Muhammad Fayyaz Mumtaz, Fikih Wabah: Panduan Keagamaan di Masa Pandemi (Jakarta: Yayasan Rumah Kita Bersama Indonesia, 2020), 1.

19 'Abdul Halim 'Uways, Fikih Statis dan Fikih Dinamis (Bandung: Pustaka Hidayah, 1998), 1.

${ }^{20}$ Muștafà al- 'Adawi, Fiqh Pergaulan Anak Terhadap Orang Tua (Solo: Tinta Medina, 2015), 1.

21 Abü Isḥāq al- Shāțibì, Al-Muwāfaqāt (Beirut: Dār al-Kutub al-'Ilmiyyah, 2003), 20. Jāsir 'Awdah, Al-Ijtihà̃d al-Maqāsidìi (Kairo: Al-Syabkah al-'Arabiyah, 2011), 26.

${ }^{22}$ Jāsir 'Awdah, Fiqh al-Maqāshid(Herdon: International Institute of Islamic Thought, 2006), 5.
} Tribakti: Jurnal Pemikiran Keislaman Volume 32, Nomor 1, Juli 2021 
yang ditulis oleh Fuat Hasanudin. Fuat menjelaskan tentang metode-metode hukum yang digunakan oleh MUI dalam mengeluarkan sebuah produk fatwa. ${ }^{23}$ Perbedaan yang cukup mendasar antara tulisan fuat dengan penelitian ini terletak pada pendekatan yang digunakan, yakni aspek epistemologi dari fikih maqāșidi yang ada dalam putusan MUI selain juga terdapat perbedaan pada fokus dan pertanyaan penelitian.

Pertanyaan penelitian yang akan dijawab dalam artikel ini berkisar pada aspek fikih maqāṣidi yang terkandung dalam fatwa Majelis Ulama Indonesia (selanjutnya disebut MUI) Nomor 14 tahun 2021 dan tentang konstruksi epistemologi ${ }^{24}$ fikih maqāsidì. Pertanyaan penelitian ini penting untuk dijawab guna memenuhi kebutuhan teoritis tentang keberadaan fikih maqāsidi dan konstruksi epistemologi. Sekaligus menemunkan role model penerapannya dalam sebuah produk hukum Islam berupa fatwa yang dikeluarkan oleh lembaga keagamaan di Indonesia.

\section{Metode}

Jenis penelitian ini adalah kepustakaan, yakni dengan memanfaatkan dokumendokumen (tertulis) sebagai rujukan dan fokus kajian. Rujukan kepustakaan yang digunakan adalah dokumen fatwa MUI, kitab kuning (turats), artikel seputar kajian maqāsid al-sharī'ah. Data penelitian ini terbagi menjadi dua hal, yakni data tentang fatwa MUI dan maqāṣid al-shari' 'ah. Secara lebih detail, sumber data utama (primer) penelitian ini berupa dokumen fatwa MUI nomor 14 Tahun 2021 yang berisi tentang penggunaan vaksin Astrazeneca dan kitab al-Muwāfaqāt karya monumental imam alShătibì. Sumber data yang pertama (fatwa MUI) digunakan untuk menemukan aspek fikih yang bersesuaian dengan nilai-nilai maqāșid. Sedangkan sumber data utama yang kedua (al-Muwāfaqāt) difungsikan sebagai dasar pijakan dalam mengkonsepsikan maqāsid al-sharī'ah. Selain dua data utama ini, peneliti juga menggunakan data pendukung (skunder) diantaranya, Ijtihād al-Maqāṣidi karya Jāsir 'Awdah, artikel Ade Musofa berjudul Rekonstruksi Epistimologi Ilmu Ushul Fikih Berbasis Ilmu Sejarah,

${ }^{23}$ Fuat Hasanudin, "Ijtihad Maqashidi: Metodologi dan Kontekstualisasi Hukum Islam di Indonesia (Studi Fatwa-fatwa Majelis Ulama Indonesia)," Al-Mawarid: Jurnal Syari'ah dan Hukum 1, no. 2 (Agustus) (2019): 134, https://doi.org/10.20885/mawarid.vol1.iss2.art2.

24 Epistemologi merupakan salah satu bagian pening dari trilogi filsafat selain ontologi dan aksiologi. Berbeda dengan epistemologi dalam hukum Barat. Epistemologi hukum Islam dibangun melalui hubungan dialektis antara nalar dan wahyu yang dinamis. Wahyu berfungsi sebagai sebuah panduan yang diberikan oleh Tuhan pada umat manusia, sedangkan nalar difungsikan sebagai alat untuk memahami wahyu dan mendialogkannya dengan kondisi riil yang dialami oleh masyarakat. Asmawi, "Epistemologi Hukum Islam Perspektif Historis danSosiologis dalam Pengembangan Dalil," Tribakti: Jurnal Penelitian Keislaman 32, no. 1 (2021): 57, https://doi.org/10.33367/tribakti.v32i1.1393. 
serta tulisan Mohamed El-Tahir El-Mesawi berjudul Maqashid Al-Syari'ah: Meaning, Scope And Ramifications. Untuk menemukan aspek filosofis yang terkandung dalam fatwa MUI tersebut, pendekatan yang digunakan adalah filsafat hukum Islam, khususnya maqāsid al-sharī'ah, yang dipadu dengan kajian filsafat, khususnya epistemologi. Analisis data menggunakan metode content analysis. Pemilihan metode analisis didasarkan pada kebutuhan untuk menemukan aspek maqāsid al-sharī'ah yang terkandung dalam fatwa MUI. Meski pada mulanya metode ini dikembangkan untuk menganalisis karya sastra, dalam perkembangannya banyak digunakan oleh para peneliti dalam upaya analisis produk perundang-undangan dan dokumen sejenisnya, termasuk dokumen tentang fatwa MUI.

Secara teknis, penelitian ini melalui beberapa tahap. Pertama, tahap penentuan tema dan fokus kajian. Pada tahap pertama ini, penulis melakukan ulasan telaah terhadap kajian-kajian yang telah ada kemudian menetapkan fokus kajian yang berbeda dengan literatur sebelumnya. Dalam melakukan ulasan, penulis memanfaatkan sumber data berupa artikel yang telah dipublikasikan pada jurnal-jurnal. Tahap pertama ini dilakukan selama satu pekan. Kedua, tahap penetapan metode dan pengumpulan data. Pada tahap ini penulis terlebih dahulu membuat kerangka konsep metode penelitian yang akan digunakan. Selain itu, dalam upaya pemenuhan data, penulis melakukan penelusuran terhadap karya-karya sebelumnya yang akan dijadikan sebagai sumber data penelitian, baik yang utama maupun tambahan. Penelusuran karya dilakukan melalui dua cara, yakni manual untuk karya fisik (buku dan kitab) dan search engine untuk karya digital (artikel). Karya yang dianggap relevan kemudian dikumpulkan, dipilah, dan dikode sesuai dengan kebutuhan referensial penelitian. Tahap ini dilakukan selama satu pekan. Ketiga, tahap penulisan dan editing. Dalam tahap ini penulis menyusun kerangka pembahasan dan ketersambungan logika antar paragraf. Lebih dari itu, pada tahap ini penulis menyusun latar belakang, analisis terhadap data-data yang dituangkan dalam bab pembahasan serta penarikan kesimpulan. Setelah selesai pada sesi akhir, penulis melakukan telaah ulang dan penghalusan bahasa serta memastikan validitas referensi penelitian. Tahap terakhir ini memerlukan waktu selama dua pekan. 


\section{Hasil dan Pembahasan}

\section{Aspek Fikih Maqāsidi dalam Putusan Fatwa MUI Nomor 14 Tahun 2021}

Lembaga fatwa MUI menerbitkan putusan tentang hukum menggunakan vaksin covid-19 dari produk Astrazeneca pada tanggal 16 Maret tahun 2021. Berbeda dengan fatwa sebelumnya, yakni tentang hukum menggunakan vaksin covid-19 dari produk Sinovac yang suci dan halal ${ }^{25}$, fatwa MUI Nomor 14 Tahun 2021 menjadi perbincangan yang cukup hangat di tanah air. Sebab, sebagaimana diketahui vaksin Astrazeneca yang diproduksi di Korea Selatan ini, memanfaatan tripsin yang berasal dari hewan babi dalam proses pembuatannya. Tripsin dalam pembuatan vaksin berfungsi sebagai media untuk mempercepat reaksi biokimia tertentu. Dalam kasus vaksin Astrazeneca, tripsin yang berupa protein atau enzim ini digunakan sebagai media tanam virus yang akan digunakan sebagai vaksin. Setelah virus yang ditanam tumbuh, tripsin kemudian dipisahkan secara bersih, sehingga pada hasil akhir sudah tidak terdapat lagi unsur turunan hewan babi yang terkandung dalam vaksin. ${ }^{26}$

MUI melalui fatwa nomor 14 tahun 2021 menyatakan bahwa pada dasarnya vaksin Astrazeneca tergolong benda najis yang tidak boleh dikonsumsi. Kenajisan vaksin ini bahkan terkategori sebagai najis yang berat (mughallazah) sebab bersentuhan dengan unsur hewan babi saat proses produksinya. Dasar penetapan kenajisan dan keharaman yang digunakan oleh MUI diantaranya adalah ketentuan dalam surat al-Baqarah (2): 173 yang menjelaskan tentang keharaman konsumsi hewan babi disejajarkan dengan bangkai, darah, dan binatang yang disembelih bukan untuk Allah SWT. dan QS. alBaqarah (2): 168 yang berisi tentang perintah mengkonsumsi makanan halal dan tayyib (baik). ${ }^{27}$ Selain berdasar pada Al-Qur' an, dalam fatwa ini, MUI juga menggunakan hadis riwayat $\mathrm{A} b \overline{\mathrm{u}} \mathrm{D} \overline{\mathrm{a}} \mathrm{w} \mathrm{u}$ yang berisi larangan mengkonsumsi obat dari benda yang haram. ${ }^{28}$

Lebih lanjut MUI berpandangan bahwa persoalan wabah Covid-19 merupakan persoalan global yang telah sampai pada kondisi ḍarürah dan menuntut penanganan sesegera mungkin. MUI menggunakan laporan dari para ahli tentang potensi bahaya

\footnotetext{
${ }^{25}$ Komisi Fatwa MUI, "Fatwa Majelis Ulama Indonesia Nomor: 02 Tahun 2021 Tentang Produk Vaksin Covid-19 Dari Sinovac Life Sciences Co.Ltd. China dan PT. Bio Farma (Persero)” (2021), 8.

${ }^{26}$ Abdul Kadir Jaelani, Alexander A. Kurniawan, dan Lusia Indrastuti, "Pelaksanaan Standarisasi Pemberian Paten Dalam Invensi Bidang Obat-Obatan Di Indonesia," Legality: Jurnal Ilmiah Hukum 27, no. 2 (2019) (2019): 263, https://doi.org/10.22219/jihl.v27i2.10173.

${ }^{27}$ Komisi Fatwa MUI, Fatwa Majelis Ulama Indonesia Nomor: 02 Tahun 2021 Tentang Produk Vaksin Covid-19 Dari Sinovac Life Sciences Co.Ltd. China dan PT. Bio Farma (Persero), 1-2.

${ }^{28}$ Komisi Fatwa MUI, "Fatwa Majelis Ulama Indonesia Nomor: 14 Tahun 2021 Tentang Hukum Penggunaan Vaksin Covid-19 Produk Astrazeneca" (2021), 2. 
yang fatal bagi masyarakat Indonesia jika tidak segera dilalukan vaksinasi secara masal dan cepat. Sementara itu, vaksin covid-19 yang suci dan halal ketersediannya tidak lagi mencukupi untuk pemunuhan kebutuhan program vaksinasi. Pemerintah RI juga tidak memiliki kesempatan untuk memilih dan mendapatkan vaksin lain yang berhukum suci dan halal, mengingat ketersediaanya masih sangat terbatas dan diperebutkan oleh seluruh negara di dunia. Keterbatasan inilah yang menyebabkan vaksin Astrazeneca dipilih dan digunakan oleh Pemerintah RI dalam kegiatan vaksinasi, terlebih keamanan penggunaan, kemanjuran, dan mutu dari vaksin Astrazeneca juga telah dikeluarkan oleh BPOM pada tanggal 22 Februari 2021. Jaminan berupa persetujuan penggunaan vaksin dari BPOM dianggap oleh MUI sebagai indikasi terpenuhinya unsur tayyib yang terkandung dalam vaksin Astrazeneca. ${ }^{29}$

Hukum najis dan haram Astrazeneca, di satu sisi, dan kondisi darurat pada sisi lain, menjadikan MUI mengeluarkan fatwa mūbặ (boleh) mengkonsumsi vaksin tersebut. Fatwa mūbah ini berlaku secara terbatas pada kondisi darurat dan tidak didapatkannya vaksin lain yang suci dan halal, baik karena faktor kelangkaan atau karena faktor sulit untuk didapatkan. Dalam situasi kembali normal atau didapatkan vaksin yang suci dan halal, hukum penggunaan vaksin Astrazeneca kembali pada hukum aslinya, yakni haram. $^{30}$

Landasan argumentatif yang digunakan oleh MUI dalam fatwa ini diantaranya adalah surat al-Baqarah (2): 195 yang berisi larangan menjatuhkan diri dalam kerusakan dan kebinasaan, surat al-Baqarah (2): 173) tentang bolehnya mengkonsumsi barang haram dalam kondisi terpaksa, hadis tentang perintah minum kencing unta, hadis tentang tidak boleh mendatangkan bahaya pada diri sendiri (darar) dan atas orang lain ( dirār). Disamping bersumber dari Al-Qur'an dan hadis, fatwa ini juga didasarkan pada beberapa pendapat ulama fikih yang memperbolehkan menggunakan benda najis sebagai obat dengan syarat-syarat tertentu, serta dilengkapi dengan kaidah fikih (legal maxim) terkait perubahan hukum dalam kondisi darurat. ${ }^{31}$

Perubahan hukum tentang bolehnya mengkonsumsi vaksin Astrazeneca dalam kondisi mendesak merupakan pertentangan antara kebaikan yang terdapat dalam menjauhi benda najis dan kebaikan yang hendak diwujudkan dalam menkonsumsinya.

\footnotetext{
${ }^{29}$ Komisi Fatwa MUI, 10.

${ }^{30}$ Komisi Fatwa MUI, 12.

${ }^{31}$ Komisi Fatwa MUI, 5.
} 
Jika kita bandingkan, tujuan larangan mengkonsumsi benda haram adalah untuk menjaga kesehatan dan kebaikan diri kita, baik secara fisik maupun spiritualitas. Sedangkan tujuan diperbolehkannya mengkonsumsi vaksin Astrazeneca adalah untuk mengurangi jumlah kematian, kesakitan, dan penularan wabah dalam jangka yang lebih panjang adalah untuk segera mengakhiri pandemi covid-19. ${ }^{32}$

Nilai kebaikan dalam bolehnya mengkonsumsi vaksin Astrazeneca masuk dalam kategori kebutuhan primer (ḍarūî́) berupa menjaga nyawa (hifž al-nafs) dan keberlanjutan kehidupan umat manusia. Nilai kebaikan ini tentu lebih unggul jika dibandingkan dengan menjaga diri dari benda najis yang tidak sampai menyebabkan terancamnya nyawa sebagaimana pendapat yang disampaikan oleh Ibnu Qudāmah. ${ }^{33}$ Melihat betapa mendesaknya kondisi pandemi, MUI melalui fatwanya juga telah menetapkan adanya kewajiban bagi umat Islam untuk mengikuti program vaksinanasi yang diselenggarakan oleh pemerintah. Unggulnya kebaikan dalam penggunaan vaksin Astra Astrazeneca dalam konteks pandemi menjadi alasan utama kebolehan mengkonsumsinya. Fatwa MUI dengan demikian telah melakukan sebuah uji tarjịh maqāsidi terhadap dua kebaikan yang ada, kebaikan dalam mengkonsumsi dan kebaikan melarang konsumsi. Uji tarjịh maqāsidi ini pada akhirnya melahirkan produk hukum fikih berparadigma maqāṣid yang disebut sebagai fikih maqāṣidi. Sebuah gagasan fikih responsif yang dilahirkan melalui ijtihad berbasis maqạșid al-shari ‘ ah demi terciptanya kesejahteraan dan kemakmuran seluruh manusia, baik saat hidup di dunia maupun nanti saat di akhirat. ${ }^{34}$

Satu temuan menarik yang barangkali sering luput dicermati lebih mendalam adalah perubahan hukum yang semula haram menjadi mübaḥ sebagai bentuk respons terhadap perubahan dan kemendesakan kondisi. Tampaknya, perubahan hukum semacam ini sesuatu yang dimaklumi oleh para akademisi hukum Islam. Namun demikian, perubahan hukum tersebut ternyata bukan semata-mata karena perubahan kondisi. Lebih dari itu, dalam perubahan hukum semacam ini yang terjadi sebenarnya adalah proses menemukan dan mewujudkan nilai kemaslahatan dalam sebuah produk hukum. Dengan demikian dapat dikatakan bahwa produk hukum adalah bersifat dinamis

\footnotetext{
${ }^{32}$ Komisi Fatwa MUI, 9.

33 'Abdullāh Ibnū Qudāmah, Al-Mughnī, Vol. 11 (Beirut: Dar al-Fikr, 1985), 74.

${ }^{34}$ Hasanudin, "Ijtihad Maqashidi: Metodologi dan Kontekstualisasi Hukum Islam di Indonesia (Studi Fatwa-fatwa Majelis Ulama Indonesia)," 136.
} 
(mutaghayyir) yang harus mengikuti pada kemasalahatan yang bersifat statis (thābit), sekalipun berada pada hal-hal yang semula diharamkan melalui teks-teks transendental.

\section{Menggagas Bangunan Epistemologi Fikih Maqāṣidi}

Ilmu fikih dikenal sebagai sebuah ilmu yang secara khusus mengkaji hukum shara bersifat terapan hasil rumusan dari dalil-dalil spesifik agama. Berbeda dengan ilmu ushul fikih yang membahas tentang dalil-dalil umum dalam proses perumusan dan penemuan hukum, ilmu fikih lebih merupakan kumpulan dari hukum-hukum yang sudah jadi melalui sebuah proses ijtihad yang ketat dan berfungsi sebagai pedoman bagi umat Islam dalam menjalankan ajaran agamanya. ${ }^{35}$

Sebagai pedoman menjalankan aktifitas keagamaan, fikih telah hidup bersamaan dengan kemunculan agama Islam itu sendiri. Pada era kenabian, fikih mewujud dalam bentuk perilaku-perilaku yang diajarkan dan dicontohkan langsung oleh Nabi SAW. Aktifitas ijtihad hukum di kalangan umat pada era ini belum tampak secara signifikan, meskipun legalitasnya sudah ditetapkan oleh Nabi SAW sendiri saat Mu‘āa Ibn Jabal didelegasikan ke tanah Yaman. ${ }^{36}$ Sepeninggal Nabi SAW, kebutuhan untuk berijtihad terlihat cukup mendesak di kalangan para sahabat. Upaya untuk mendialogkan antara nas transendental, Al-Qur'an dan hadis, dengan kondisi riil umat Islam perlu sesegera mungkin untuk dilakukan guna memenuhi kebutuhan kekosongan hukum terhadap peristiwa yang sama sekali belum pernah muncul pada era Nabi SAW. masih hidup. Pada era ini, dikenal cukup banyak produk hukum hasil ijtihad yang dilakukan oleh para sahabat. Pengumpulan dan pembukuan Al-Qur'an ${ }^{37}$, standarisasi bacaan Al-Qur'an ${ }^{38}$, pelaksanaan shalat tarawih secara berjama' $\mathrm{hh}^{39}$ merupakan sederetan contoh ijtihad hukum keagamaan yang dihasilkan oleh para sahabat.

Fikih mengalami perkembangan pasca era sahabat berakhir atau biasa dikenal dengan era tabi'in. Seiring dengan meluasnya pengaruh dan wilayah kekuasaan Islam, diskursus fikih mulai mengambil bentuk dalam pola mazhab sebagai bentuk respons

${ }^{35}$ Ade Musofa, "Rekonstruksi Epistimologi Ilmu Ushul Fikih Berbasis Ilmu Sejarah," Al-Adyan 13, no. 2 (Juli-Desember) (2018): 197, https://doi.org/10.24042/ajsla.v13i2.3296.

${ }^{36}$ Sulayman Abū Dāwūd, Sunan Abī Dāwūd, Vol. 3 (Beirut: Dār al-Kitāb al-’Arābī, 2011), 330.

${ }^{37}$ Munawir, "Problematika Seputar Kodifikasi Al-Qur'an (Sebuah Kajian Kesejarahan Perspektif Kesarjanaan Muslim dan Analisis Kritis Kesarjanaan Barat)," Maghza: Jurnal Ilmu Al-Qur'an dan Tafsir 3, no. 2 (Juli-Desember) (2018): 152, https://doi.org/10.24090/maghza.v3i2.2128.

${ }^{38}$ Kalimatul 'Ulya dan Saidah, "Rijalul Qur'an: Membincang Sejarah Para Penulis Wahyu," QOF: Jurnal Studi Al-Qur'an dan Tafsir 1, no. 1 (Januari) (2017): 56, https://doi.org/10.30762/qof.v1i1.929.

${ }^{39}$ Muḥammad Shamsuddin al- Qurțūbī, Al-Jāmi' Li Aḥkām al-Qur'ān, Vol. 2 (Riyad: Dār 'Alam al-Kutub, 2003), 87.

Tribakti: Jurnal Pemikiran Keislaman

Volume 32, Nomor 1, Juli 2021 
terhadap dinamika kehidupan umat Islam di berbagai wilayah belahan dunia. Pada mulanya, mazhab fikih terbentuk berdasarkan pada ragam dan corak pemikiran hukum Islam kedaerahan. Pengembangan mazhab fikih daerah pada pusat-pusat kajian intelektual yang terkonsentrasi pada wilayah Hijaz (Mekah dan Madinah), Irak, Mesir dan Syam pada gilirannya memunculkan dua tipologi; Mazhab Kufah dengan corak rasionalis (ahl al-ra'y) dan mazhab Hijaz dengan corak tekstualis (ahl al-hadis). ${ }^{40}$ Tipologi fikih dengan mazhab daerah kemudian disusul dengan kemunculan mazhab fikih perorangan berjumlah sekurang-kurangnya 13 (tiga belas), dengan menempatkan 4 (empat) mazhab utama yang terus bertahan dan berkembang hingga masa modern ini, yakni Hanafi (80 H.-150 H.), Maliki (93 H.-179 H.), Syafi’i (150 H.-2014 H.), dan Hanbali (164 H.-241 H.). Disamping madzhab perorangan, pemikiran fikih juga terwarnai oleh corak kelompok tertentu, seperti madzhab Syi'ah. ${ }^{41}$

Fikih mazhab perorangan tampaknya merupakan puncak kemapanan ilmu fikih itu sendiri. Kajian fikih pada era selanjutnya atau era pengikut madzhab perorangan merupakan kerja meringkas (ikhtiṣār), menjelaskan (tarshịh), dan memberi catatan pinggir (tahshiyyah) terhadap pemikiran fikih yang terdokumentasi dalam kitab-kitab fikih mazhab atau yang dikenal dengan istilah kitab kuning (dalam makna khusus). Kemapanan fikih mazhab perorangan menjadikan seluruh aktifitas intelektual hukum Islam harus menginduk pada pemikiran imam mazhab yang telah ada, baik secara qaw $\bar{i}$ (tekstualis) maupun manhaji (metodologis). Di Indonesia, misalnya, hal ini tampak dalam kegiatan perumusan dan penemuan hukum yang dilakukan oleh lembaga fatwa MUI, Bahtsul Masail NU, bahkan dalam perumusan hukum positif seperti perda syari'ah. Kemapanan fikih mazhab perorangan pada satu sisi telah memperkecil peluang kelahiran fikih mazhab baru. Namun pada sisi yang lain telah mendorong kemunculan kajian fikih dengan pendekatan tematik dan dengan mengangkat isu-isu strategis sebagai corak utama kajian. Hal ini sebagaimana tampak dalam gagasan fiqhiyah para cendekiawan Muslim di Indonesia, seperti fikih sosial yang digagas oleh M.A. Sahal Mahfudz. ${ }^{42}$

\footnotetext{
40 Abdul Basith Junaidy, "Dialektika Hukum Islam Pada Masa Awal Islam," Al-Jinayah: Jurnal Hukum Pidana Islam 2, no. 2 (Desember) (2016): 427, https://doi.org/10.15642/aj.2016.2.2.420-439.

${ }^{41}$ Sirry, Sejarah Fiqih Islam: Sebuah Pengantar, 1995, 79.Mun'im A. Sirry, Sejarah Fiqih Islam: Sebuah Pengantar (Surabaya: Risalah Gusti, 1995), 79.

${ }^{42}$ Mahfudz, Nuansa Fiqh Sosial, 1.
} 
Semaraknya kajian fikih tematik dapat dikatakan sebagai salah satu indikator telah terjadi transformasi nuansa dan paradigma fikih, dari yang semula teosentris-vertikal menuju antroposentris-horizontal. Transformasi ini dapat dimaknai bahwa fikih telah melakukan proses adaptasi terhadap isu-isu sentral kemanusian. Pribumisasi Islam, meminjam istilah Abdurrahman Wahid ${ }^{43}$, khususnya dalam bidang hukum merupakan usaha yang selayaknya diusahakan secara konsisten dan bekelanjutan. Pribumisasi hukum Islam jika memang diperlukan, dalam batas tertentu, dapat dilakukan melalui perubahan-perubahan aturan-aturan fikih. Sebuah perubahan yang keberadaananya telah diniscayakan sendiri oleh fikih sebagaimana sebuah adagium legal maxim "lā yunkar taghayyur al-aḥkām bi taghayyur al-azmān" (tidaklah dapat dipungkiri adanya perubahan hukum disebabkan perubahan konteks). ${ }^{44}$

Adaptasi fikih dengan pemenuhan kebutuhan terbaik bagi masyarakat, baik dalam jangka pendek maupun panjang, mengantarkannya kembali bersentuhan dengan aspek terdalam filsafat hukum Islam. Fikih tidak lagi hanya soal bunyi dan pemahaman teks pendapat mazhab, akan tetapi juga mulai mempertimbangkan aspek tujuan yang hendak dicapai dengan diberlakukannya aturan tersebut. Pada titik inilah terjadi dialektika antara fikih dengan maqāsid al-sharī $a h$. Dialektika ini bukan dimaksudkan bahwa fikih tercerabut dari akarnya, akan tetapi pergerakan hasil akhir fikih harus sesuai dengan nilai-nilai maqāsid. Dengan basis maqāṣid al-sharī‘ah, rumusan hukum fikih dapat menyelesaikan problematika kegamaan dan sosial kemasyarakatan yang tidak dapat lagi diselesaikan oleh rumusan fikih klasik yang telah ada. ${ }^{45}$

Fikih maqāṣidi secara sederhana dapat diartikan sebagai fikih yang berorientasi pada keterwujudan maqāṣid al-sharī'ah. Fikih maqāsidi adalah cara pandang yang menempatkan fikih sebagai instrumen yang harus dapat menyelesaikan dan mendamaikan kesenjangan antara rumusan-rumusan hukum yang telah ada dengan kondisi sosial kemasyarakatan. Dengan instrumen ini, teks-teks suci agama yang telah terputus pasca wafatnya Nabi akan didialogkan dengan dinamika kehidupan masyarakat yang terus berkembang. Hubungan dialogis antara teks dan konteks diharapkan mampu

\footnotetext{
${ }^{43}$ Tri Wahyudi Ramdhan, "Islam Nusantara: Pribumisasi Islam Ala NU," Al-Insyiroh: Jurnal Studi Keislaman 2, no. 2 (2018): 77, https://doi.org/10.35309/alinsyiroh.v2i1.3333.

${ }^{44}$ Aḥmad al- Zarqā, Sharḥ Al-Qawā'id Al-Fiqhiyyah (Damaskus: Dār al-Qalam, 1989), 129.

45 Ahmad Imam Mawardi, "The Urgency of Maqasid Al-Shariah Reconsideration in Islamic Law Establishment for Muslim Minorities in Western Countries," International Journal of Innovation, Creativity and Change 12, no. 9 (2020): 399.
}

Tribakti: Jurnal Pemikiran Keislaman Volume 32, Nomor 1, Juli 2021 
melahirkan serangkaian aturan dan nilai hukum yang dapat menciptakan harmoni dalam kehidupan umat manusia, baik kapasitasnya sebagai makhluk individu maupun sosial. ${ }^{46}$

Dialog teks dan konteks dalam gagasan pembentukan fikih maqāṣidi telah dicontohkan dengan sangat baik oleh salah satu sahabat terkemuka Nabi SAW. 'Umar Ibn Khațāāb. Saat menjadi khalifah, 'Umar telah melakukan moratorium bagi "muallafah qulūbuhum" sebagai salah satu kelompok penerima zakat meski tersurat dalam QS. alTaubah (9): 60.

'Umar berpandangan bahwa tujuan utama dari pemberian zakat pada kelompok ini adalah sebagai rangsangan agar mereka mau bergabung dalam barisan umat Islam sehingga Islam menjadi agama yang kuat. Namun, pada saat kepemimpinan Abu Bakar dan 'Umar, umat Islam sudah sedemikian kuat sehingga tidak membutuhkan lagi keberadaan mereka sehingga ketentuan hak menerima zakat tidak lagi diberlakukan. ${ }^{47}$ Kebijakan hukum 'Umar ini tidak mendapat pertentangan dari para sahabat Nabi yang lain ${ }^{48}$, sehingga posisinya dapat dikategorikan sebaga sebuah ijmak atau konsensus.

Selain hal di atas, fikih maqāșidi yang telah dilakukan oleh 'Umar adalah tentang pembebasan seorang pencuri wanita. Barang yang dicuri oleh perempuan tersebut sebenarnya telah mencapai batas ukuran (niṣāb) hukuman potong tangan. Tetapi karena ia melakukannya dalam kondisi paceklik, 'Umar tidak menjatuhkan hukuman potong tangan. ${ }^{49}$ Kebijakan 'Umar ini sekilas tampak bertentangan dengan ketentuan surat alMaidah (5): 38: Wa al-sāriq wa al-sāriqah faqta'a'u aydiyahumā jazāa bi mā kasabā nakālān min Allāh. Wa Allāh 'Azīz Hakìm. Ayat ini memaparkan tentang pemberlakuan hukuman potong tangan bagi para pencuri, baik pria maupun wanita. Di dalamnya tidak disebutkan kondisi-kondisi seseorang dapat dibebaskan dari hukuman. 'Umar, dengan paradigma fikih maqāssidi, dengan sangat baik mendahulukan kepentingan menjaga nyawa seseorang (hifz al-nafs) pada kondisi paceklik darurat daripada menjaga harta (hifź al-mā̄) sebagaimana terkandung dalam ayat tersebut.

\footnotetext{
${ }^{46}$ Mohamed El-Tahir El-Mesawi, "Maqashid Al-Syari'ah: Meaning, Scope And Ramifications," Al-Shajarah: Journal Of The International Institute Of Islamic Thought And Civilization (ISTAC) 25, no. 2 (2020): 265.

${ }^{47}$ Fahmi Jawwas, “Posisi Nash Dalam Ijtihad 'Umar Ibn Khattab,” Hunafa: Jurnal Studia Islamika 10, no. 2 (Desember) (2013): 374, https://doi.org/10.24239/jsi.v10i2.36.359-379.

48 'Abdur Raḥmān Suyūṭi, Al-Durr al-Manthūr, Vol. 4 (Beirut: Dār al-Fikr, 1993), 224.

${ }^{49}$ Nailul Rahmi, "Hukuman Potong Tangan Perspektif Al-Qur'an Dan Hadis," Ulunnuha 7, no. 2 (2018): 54, https://doi.org/10.15548/ju.v7i2.254.
} 
Jauh sebelum Umar, Nabi SAW. sendiri telah mencontohkan tentang penerapan fikih maqāsidi saat berupaya melakukan deponering terhadap kasus hukum berupa perzianahan yang menimpa pada diri sahabat Mā'iz Ibn Mālik. Saat mengaku dan berupaya meminta dijatuhkan hukuman atas perbuatannya, Nabi dengan sengaja beberapa kali mengalihkan pengakuannya agar ia tidak perlu menjalani hukuman. Sebab, tujuan dari pemberlakukan hukuman dalam Islam adalah memberikan efek jera pada pelakunya, dan Mā'iz benar-benar telah jera dari perbuatannya dengan indikasi berani mengaku pada Nabi atas perbuatannya dan telah bertaubat. ${ }^{50}$ Meski upaya deponering yang dilakukan oleh Nabi tidak berhasil dikarenakan sikap dari Mā'iz yang bersikeras minta dihukum, satu hal yang dapat ditangkap dari peristiwa ini adalah keberadaan fikih maqashidi telah hidup pada era awal Islam.

Indikasi adanya fikih maqāṣidi juga disebut secara implisit dalam surat al-An‘ām (6): 108 yang berisi larangan mencela sesembahan agama lain. Pada satu sisi, umat Islam memiliki kewajiban untuk mengakui secara totalitas tentang keberadaan Allah SWT, satu-satunya tuhan yang berhak dan harus disembah, sekaligus menegasikan kemungkinan adanya tuhan selain-Nya. Namun, pada sisi yang lain Al-Qur'an melarang umat Islam menggangu keyakinan ketuhanan umat lain sebab akan menimbulkan respons balik yang negatif dari penganut agama lain. Upaya mencela "tuhan" agama yang lain sebenarnya dapat dimaknai sebagai konsekuensi logis dari penegasan adanya tuhan selain Allah SWT. Namun, jika aturan ini diperbolehkan akan berdampak pada kurang nyamannya umat Islam dalam menjalankan ajaran keagamaannya sebab tersibukkan dengan kegiatan menangkal counter attack dari pengikut agama lain. Dari sini diketahui bahwa pemberlakuan QS. al-An‘ām (6): 108 secara tersirat merupakan upaya penjagaan agama sebagai salah satu unsur penting dari maqāṣid al-shari ‘ ah.

Berdasar pada penjelasan di atas disimpulkan bahwa fikih maqāṣidìmemiliki dasar filosofis yang mapan dan kuat dalam khazanah perkembangan hukum Islam. Sebab ia didukung dan dirumuskan berdasarkan teks Al-Qur'an, hadis, dan ijmak para sahabat. Cara pandang fikih maqạsidi sebenarnya juga telah dicontohkan oleh ulama mazhab melalui serangkaian rumusan kerja metodologis penemuan seperti istị̣sān, faṭ̣ aldharī 'ah, sadd al-dhari 'ah, al-maṣlahah, al-istiṣlāh, dan al-maṣlahah al-mursalah. Dalam pada itu, tentang persoalan $m u$ 'àmalah jamak dikenal adagium " al-'ibrah fí al-'uqūd bi

\footnotetext{
${ }^{50}$ Abū Al-Ḥusayn Muslim, Saḥịh Muslim, Vol. 5 (Kairo: Dār Ihyā' al-Kutub al-’Arabiyyah, 1955),
} 119. 
al-maqāṣid wa al-ma‘āni là bi alfă wa al-mabānỉ' (yang dianggap dalam sebuah transaksi adalah tujuan dan makna dari sebuah redaksi, bukan bunyi tekstualis dan bentuk-bentuk ucapan). ${ }^{51}$ Namun demikian, serangkaian kerja intelektual ini belum menempatkan secara spesifik maqāṣid al-sharī ${ }^{\circ}$ ah sebagai tujuan akhir yang hendak dicapai dari rumusan fikih itu sendiri.

Paradigma fikih maqāsidi sebagai sebuah sistem dapat dikembangkan melalui keterlibatan dan penyatuan lima unsur sekaligus, yakni ushul fikih, fikih, realitas, maqāṣid al-shari ${ }^{`} a h$, kaidah fikih. Ushul fikih berfungsi sebagai basis perumusan sekaligus untuk menjamin tidak tercerabutnya fikih dari batas-batas nas transendental. Fikih sebagai produk rumusan ushul fikih kemudian dicoba didialogkan dengan kondisi riil masyarakat, terkait efektifitasnya dengan kemungkinan terwujudnya tujuan-tujuan yang ada dalam khazanah maqāṣid al-shari ${ }^{`} a h$.

Rumusan fikih yang kurang bersesuaian dengan maqashid al-Syari'ah perlu disesuaikan melalui serangkaian proses eklektis dan tarjih dengan memanfaatkan kemungkinan adanya rumusan fikih lain yang paling tepat (așlah). Bahkan pada bidang muamalah, dalam kondisi ketika rumusan fikih yang paling tepat terkesan bertentangan dengan bunyi tekstual naṣs transendental, rumusan tersebut tetap dapat diloloskan sebagai upaya memenuhi kebutuhan hukum terbaik bagi masyarakat. Meminjam istilah Najmuddin al-Ṭūfi, penjagaan keterwujudan maṣlaḥah harus lebih didahalukan dari pada naṣ transendental. Upaya penjagaan ini dapat dilakukan melalui cara takhșịs (privilese) dan bayān (penjelasan), bukan melalui pola negasi dan liberasi. ${ }^{52}$ Determinasi mașlaḥah atas naṣ disebabkan karena kemaslahatan merupakan nilai yang disepakati, sedangkan dalam nas sering kali terjadi pertentangan dalam hal penanfsiran dan penerapannya. ${ }^{53}$ Memprioritaskan hal yang telah disepakati tentu lebih dapat diterima dibanding mendahukukan sesuatu yang masih diperselisihkan. Sebuah adagium legal maxim mengatakan "Iā yunkar al-mukhtalafu fỉhi wa innamā yunkar al-mujma" 'alayh" (pengingkaran terhadap masalah yang masih diperselisihkan tidaklah dapat diterima, sebaliknya pengingkaran harus terhadap susuatu yang telah menjadi konsensus). ${ }^{54}$

${ }^{51}$ Zarqā, Sharh Al-Qawā'id Al-Fiqhiyyah, 7.

${ }^{52}$ Najmuddin al- Ṭüfi, Al-Ta'yīn fï Sharh al-Arba'īn (Beirut: Muassasat al-Rayyān, 1998), 238.

${ }^{53}$ Ṭüfi, 259.

${ }^{54}$ 'Abdur Raḥmān al- Suyūṭi, Al-Ashbāh wa Al-Nazāir, Vol. 1 (Beirut: Dār al-Kutub al-'Ilmiyyah, 1982), 158. 
Sedangkan fungsi dari kaidah fikih dalam fikih maqāșidi adalah sebagai instrumen sinkronisasi antara rumusan-rumusan fikih yang telah jadi dengan nilai-nilai yang terkandung dalam maqāṣid al-sharī 'ah. Sebagaimana diungkapkan Mawardi, maqāsid alshari' 'ah, memiliki keterkaitan yang cukup erat dan saling melengkapi dengan nilai-nilai universal dalam kaidah fikih, khususnya pada kaidah-kaidah pokok yang berjumlah lima. ${ }^{55}$ Titik temu keduanya terdapat pada tujuan akhir yang hendak diwujudkan, yakni mendapatkan kebaikan dan menghindari kerusakan.

Ukuran kebenaran dalam fikih maqāṣidi adalah efektifitasnya dalam menjamin keterwujudan sebuah kemaslahatan. Apabila dikaitkan dengan tiga teori kebenaran yang ada, kebenaran fikih maqāsidi termasuk dalam kategori kebenaran pragmatis. Dalam kategori ini, rumusan fikih maqāsidì harus benar-benar dapat bernilai guna (utility) untuk mengisi kebutuhan hukum masyarakat. Selain itu, rumusan fikih maqashidi harus bersifat sederhana sehingga dapat dijangkau oleh pemahaman mayoritas umat Islam dan dapat dilaksanakan dengan sebaik-baiknya (workability). Pada akhirnya, rumusan hukum dalam fikih maqashidi harus dapat berdampak secara maksimal pada kepuasan para pelaku hukumnya (satisfactory consequencies).

\section{Kesimpulan}

Atas dasar pembahasan, dapat ditarik keseimpulan; Pertama, fatwa MUI nomor 14 Tahun 2021 dalam proses perumusannya telah menganut paradigma fikih maqạsidì. Hal ini tampak terutama pada proses tarjih yang telah dilaluinya. MUI telah dengan sangat cermat melakukan perbandingan kemaslahatan yang akan ditimbulkan antara menghindarkan diri dari najis dan keharamanan dengan kemaslahatan menggunakan vaksin Astrazeneca yang secara nyata berhukum najis. Sehingga dalam kesimpulan akhirnya, MUI memberikan fatwa bolehnya menggunakan vaksin Astrazeneca yang berhukum najis demi mewujudkan kemaslahatan yang lebih fundamental, yakni keberlangsungan hidup manusia (hifž al-nafs).

Kedua, bangunan epsitemologi fikih maqāșidì dapat diketengahkan melalui tiga lingkup rumusan, yakni dasar, paradigma, dan ukuran kebenaran. Fikih maqāșidi bersumber pada naș transendental, Al-Qur'an dan hadis, dan juga konsensus (ijmak). Paradigma fikih maqāsidìi dibangun atas hubungan intergal lima unsur utama perumusan

${ }^{55}$ Mawardi, Fiqh Minoritas: Fiqh al'Aqalliyat dan Evolusi Maqashid al-Syari'ah dari Konsep ke Pendekatan, 233.

Tribakti: Jurnal Pemikiran Keislaman

Volume 32, Nomor 1, Juli 2021 
hukum Islam, yakni ushul fikih, fikih, realitas, maqāṣid al-sharī'ah, dan kaidah fikih. Ukuran kebenaran dalam fikih maqāsidì didasarkan pada aspek kegunaannya (pragmatis) dengan menggunakan instrumen berupa utility (nilai guna), workability (fungsi kerja), satisfactory consequencies (berdampak kepuasan).

\section{Daftar Pustaka}

'Adawì, Muṣtafāa al-. Fiqh Pergaulan Anak Terhadap Orang Tua. Solo: Tinta Medina, 2015.

Ahmad, Rumadi. Fikih Persaingan Usaha. Jakarta: PP LAKPESDAM NU, 2019.

Al-Bukhārī, Muhammad Ibn Ismā'ìl. Șahīh Al-Bukhārī, Vol. 1. Beirut: Dār Ibn Kathīr, 1987.

Ali, Mukti, Roland Gunawan, Ahmad Hilmi, dan Jamaluddin Muhammad. Fikih Kawin Anak. Depok: PT. Melvana Media Indonesia, 2015.

Al-Rasyid, Harun. Fikih Korupsi: Analisis Politik Uang di Indonesia Dalam Perspektif Maqashid al-Syari'ah. Jakarta: Kencana, 2017.

Arifiati, Alifatul. Menggagas Fiqh Ikhtilaf: Potret dan Prakarsa Cirebon. Disunting oleh Marzuki Wahid. Cirebon: Lembaga Fahmina, 2017.

Asmani, Jamal Ma'mur, dan Umdatul Baroroh. Fiqh Pernikahan: Studi Pernikahan Usia Dini Dalam Pandangan Ulama. Yogyakarta: Aswaja Pressindo, 2019.

Asmawi. "Epistemologi Hukum Islam Perspektif Historis danSosiologis dalam Pengembangan Dalil.” Tribakti: Jurnal Penelitian Keislaman 32, no. 1 (2021): 5776. https://doi.org/10.33367/tribakti.v32i1.1393.

'Awdah, Jāsir. Al-Ijtihād al-Maqāṣidì. Kairo: Al-Syabkah al-'Arabiyah, 2011.

Fiqh al-Maqāshid. Herdon: International Institute of Islamic Thought, 2006.

Baroroh, Umdatul, dan Tutik Nurul Jannah. Fikih Sosial: Masa Depan Fiqh Indonesia. Pati: Pusat Fisi, 2016.

Chudlori, Muhammad Yusuf. Fikih Sosial Praktis Dari Pesantren. Bandung: CV Marja, 2015.

Dāwūd, Sulayman Abū. Sunan Abī Dāwūd, Vol. 3. Beirut: Dār al-Kitāb al-’Arābī, 2011.

El-Mesawi, Mohamed El-Tahir. "Maqashid Al-Syari'ah: Meaning, Scope And Ramifications." Al-Shajarah: Journal Of The International Institute Of Islamic Thought And Civilization (ISTAC) 25, no. 2 (2020): 263-95.

Ghozali, M. Lathoif, M. Helmi Umam, FY. Iwanebel, Sulanam Sulanam, dan A. Mahfudz Nazal. Fiqih Lalu Lintas: Tuntunan Islam Dalam Berkendara Secara Aman. Surabaya: UIN Sunan Ampel Press, 2019.

Hasanudin, Fuat. "Ijtihad Maqashidi: Metodologi dan Kontekstualisasi Hukum Islam di Indonesia (Studi Fatwa-fatwa Majelis Ulama Indonesia)." Al-Mawarid: Jurnal 
Syari'ah dan Hukum 1, no. 2 (Agustus) (2019): 135-52. https://doi.org/10.20885/mawarid.vol1.iss2.art2.

Hilmi, Achmat, Jamaluddin Mohammad, dan Muhammad Fayyaz Mumtaz. Fikih Wabah: Panduan Keagamaan di Masa Pandemi. Jakarta: Yayasan Rumah Kita Bersama Indonesia, 2020.

Jaelani, Abdul Kadir, Alexander A. Kurniawan, dan Lusia Indrastuti. "Pelaksanaan Standarisasi Pemberian Paten Dalam Invensi Bidang Obat-Obatan Di Indonesia." Legality: Jurnal Ilmiah Hukum 27, no. 2 (2019) (2019): 259-74. https://doi.org/10.22219/jihl.v27i2.10173.

Jawwas, Fahmi. "Posisi Nash Dalam Ijtihad 'Umar Ibn Khattab.” Hunafa: Jurnal Studia Islamika 10, no. 2 (Desember) (2013): $359-79$. https://doi.org/10.24239/jsi.v10i2.36.359-379.

Junaidy, Abdul Basith. "Dialektika Hukum Islam Pada Masa Awal Islam.” Al-Jinayah: Jurnal Hukum Pidana Islam 2, no. 2 (Desember) (2016): 421-39. https://doi.org/10.15642/aj.2016.2.2.420-439.

Komisi Fatwa MUI. Fatwa Majelis Ulama Indonesia Nomor: 02 Tahun 2021 Tentang Produk Vaksin Covid-19 Dari Sinovac Life Sciences Co.Ltd. China dan PT. Bio Farma (Persero) (2021).

- Fatwa Majelis Ulama Indonesia Nomor: 14 Tahun 2021 Tentang Hukum Penggunaan Vaksin Covid-19 Produk Astrazeneca (2021).

Madjid, Nurcholish, Kautsar Azhari Noer, Komaruddin Hidayat, Masdar Farid Ma'udi, Zainun Kamal, Zuhairi Misrawi, Budhy Munawar- Rachman, dan Ahmad Gaus. Fiqih Lintas Agama: Membangun Masyarakat Inklusif-Pluralis. Disunting oleh Mun'im A. Sirry. Jakarta: Yayasan Wakaf Paramadina, 2004.

Mahfudz, Sahal. Nuansa Fiqh Sosial. Yogyakarta: LKiS, 1994.

Majid, Nur Kholis. Fikih Sosial Responsif \& Solutif. Surabaya: CV. Raziev Jaya, 2018.

Mawardi, Ahmad Imam. Fiqh Minoritas: Fiqh al'Aqalliyat dan Evolusi Maqashid alSyari'ah dari Konsep ke Pendekatan. Yogyakarta: LKiS, 2010.

-. "The Urgency of Maqasid Al-Shariah Reconsideration in Islamic Law Establishment for Muslim Minorities in Western Countries." International Journal of Innovation, Creativity and Change 12, no. 9 (2020): 388-404.

Muhajir, Afifuddin. Fiqh Tata Negara. Yogyakarta: CV. IRCiSOD, 2017.

Munawir. "Problematika Seputar Kodifikasi Al-Qur'an (Sebuah Kajian Kesejarahan Perspektif Kesarjanaan Muslim dan Analisis Kritis Kesarjanaan Barat)." Maghza: Jurnal Ilmu Al-Qur'an dan Tafsir 3, no. 2 (Juli-Desember) (2018): 148-63. https://doi.org/10.24090/maghza.v3i2.2128.

Muslim, Abū Al-Husayn. Saḥịh Muslim, Vol. 5. Kairo: Dār Ihyā' al-Kutub al'Arabiyyah, 1955.

Musofa, Ade. "Rekonstruksi Epistimologi Ilmu Ushul Fikih Berbasis Ilmu Sejarah.” AlAdyan 13, no. 2 (Juli-Desember) (2018): 193-229. https://doi.org/10.24042/ajsla.v13i2.3296.

Tribakti: Jurnal Pemikiran Keislaman

Volume 32, Nomor 1, Juli 2021 
Nakha'i, Imam, dan Marzuki Wahid. Seri Fiqih Keseharian Buruh Migran. Bandung: CV. Mujahid Press, 2015.

Qudāmah, 'Abdullāh Ibnū. Al-Mughnī, Vol. 11. Beirut: Dar al-Fikr, 1985.

Qurțūbī, Muhammad Shamsuddin al-. Al-Jāmi' Li Aḥkām al-Qur'ān, Vol. 2. Riyad: Dār 'Alam al-Kutub, 2003.

Rahman, Abd. Fikih Sosial: Individu dan Masyarakat dalam Interaksi. Disunting oleh Darmawati. Makassar: Alauddin University Press, 2012.

Rahmi, Nailul. "Hukuman Potong Tangan Perspektif Al-Qur'an Dan Hadis." Ulunnuha 7, no. 2 (2018): 53-70. https://doi.org/10.15548/ju.v7i2.254.

Ramdhan, Tri Wahyudi. "Islam Nusantara: Pribumisasi Islam Ala NU." Al-Insyiroh: Jurnal Studi Keislaman 2, no. 2 (2018): 73-91. https://doi.org/10.35309/alinsyiroh.v2i1.3333.

Shātibì, Abū Isḥāq al-. Al-Muwāfaqāt. Beirut: Dār al-Kutub al-’Ilmiyyah, 2003.

Siradj, Said Aqiel. Islam Kebangsaan: Fiqih Demokratik Kaum Santri. Jakarta: Pustaka Ciganjur, 1999.

Sirry, Mun'im A. Sejarah Fiqih Islam: Sebuah Pengantar. Surabaya: Risalah Gusti, 1995.

Sirry, Mun'im A. Sejarah Fiqih Islam: Sebuah Pengantar. Surabaya: Risalah Gusti, 1995.

Suyūṭi, 'Abdur Raḥmān. Al-Durr al-Manthūr, Vol. 4. Beirut: Dār al-Fikr, 1993.

Suyūṭi, 'Abdur Raḥmān al-. Al-Ashbāh wa Al-Naẓāir, Vol. 1. Beirut: Dār al-Kutub al'Ilmiyyah, 1982.

Syakur, Ahmad Bisyri. Fiqih Tradisi: Cara Baru Memandang Tradisi Islam di Indonesia. Bandung: Salamadani, 2013.

Ṭūfí, Najmuddin al-. Al-Ta’yīn fĭ Sharh al-Arba'īn. Beirut: Muassasat al-Rayyān, 1998.

'Ulya, Kalimatul, dan Saidah. "Rijalul Qur'an: Membincang Sejarah Para Penulis Wahyu." QOF: Jurnal Studi Al-Qur'an dan Tafsir 1, no. 1 (Januari) (2017): 51-64. https://doi.org/10.30762/qof.v1i1.929.

'Uways, 'Abdul Hạim. Fikih Statis dan Fikih Dinamis. Bandung: Pustaka Hidayah, 1998.

Wahid, Marzuki. Fiqh Indonesia: Kompilasi Hukum Islam dan Counter Legal Draft Kompilasi Hukum Islam dalam Bingkai Politik Hukum Indonesia. Cirebon: Penerbit Marja, 2014.

Yafie, Ali. Menggagas Fiqih Sosial Dari Doal Lingkungan Hidup, Asuransi Hingga Ukhuwah. Bandung: Mizan, 1994.

—. Merintis Fiqh Lingkungan Hidup. Jakarta: Ufuk Press, 2006.

Zarqāa, Aḥmad al-. Sharḥ Al-Qawā’id Al-Fiqhiyyah. Damaskus: Dār al-Qalam, 1989. 